\title{
A simultaneous occurrence of feline mammary carcinoma and uterine cystic endometrial hyperplasia in a cat
}

\author{
Ji-Hyun Yoo ${ }^{1}$, Okjin Kim ${ }^{2, *}$ \\ ${ }^{1}$ Technology Service Division, National Institute of Animal Science, Rural Development Administration, Wanju 55365, Korea \\ ${ }^{2}$ Center for Animal Resource Development, Animal Disease Research Unit, Wonkwang University, Iksan 54538, Korea
}

(Received: July 17, 2017; Revised: October 4, 2017; Accepted: October 24, 2017)

\begin{abstract}
At the time of visiting, the cat was 6-year-old female Siamese cat. The mammary mass was solid and firm and measured $2 \times 5 \mathrm{~cm}^{2}$ in greatest diameter. The uterus revealed thick uterine horn and cross sectioned wall. Histopathologically, the mammary mass revealed feline mammary carcinoma. In the uterus, cystic endometrial hyperplasia was observed. Feline leukemia virus positive reaction was detected by polymerase chain reaction. As far as we know, this is the first report of the simultaneous feline mammary carcinoma and uterine endometrial cystic hyperplasia with Feline leukemia virus infection in a cat.
\end{abstract}

Keywords: Feline leukemia virus, cats, feline mammary carcinoma, uterine hyperplasia

Tumors in mammary glands have been reported mainly in older female cats above 10 to 12 years [15]. Cats with mammary tumors are usually dead less than 1 year after the diagnosis, and the size of tumor mass is the most significant prognostic barometer [15].

Presentation of complex cystic endometrial hyperplasiapyometra (CEH-P) is not very common in cats. Clinically, these states, even those of the CEH-P complex may be asymptomatic, especially in milder cases. In $39 \%$ of cats the lesions were found circumstantially during routine ovariohysterectomies or at necropsy [11].

Feline leukemia virus (FeLV) is a cat virus that belongs to Gamma-retrovirus, a virus that causes a wide variety of invasive diseases, including lymph and bone marrow [1].

In this study, we found the simultaneous feline mammary carcinoma and uterine endometrial cystic hyperplasia with FeLV infection in a cat.

At the time of visiting, the cat was 6 years old and female Siamese cat. She appealed to the vaginal discharge and intermittent vomiting. The cat was given a health examination. Also, the mammary mass was detected on the left 2 nd mammary gland. Abdominal ultrasonography and radiographic test showed abnormal magnification in the abdominal cavity. In blood analysis, she had a neutrophilia and lymphopenia. The concentrations of progesterone and estrogen were measured, resulting in a normal range. The ovariohystectomy and mastectomy were performed. The mammary mass was solid and firm and measured $2 \times 5 \mathrm{~cm}^{2}$ in greatest diameter.
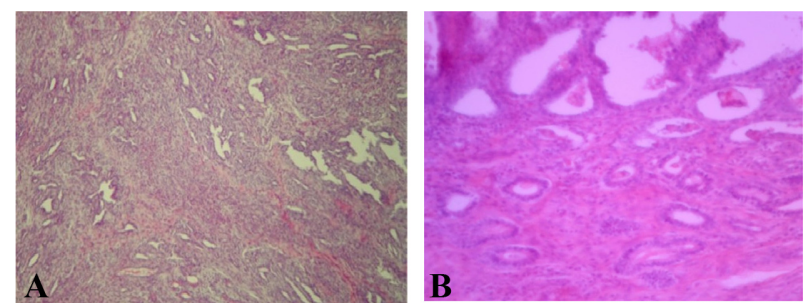

Fig. 1. Histopathological findings. (A) Mammary masses. Feline mammary carcinoma was diagnosed. (B) Uterus. The most prominent lesion was cystic endometrial hyperplasia, characterized by dilated cystic glands. H\&E stain. 100×.

Gross examination of the surgical operated uterus revealed enlarged lesions in the right horn, which had thickened wall and yellowish sticky material in the lumen. The trimmed tissues were fixed in 10\% neutral buffered formalin and embedded in paraffin. Four micrometer sections were made and stained with hematoxylin and eosin for histopathological examination.

Histopathologically, the mammary mass revealed tumor cells originated from mammary gland cells. The mammary mass revealed feline mammary carcinoma. The tumor displayed large duct almost filled with neoplastic epithelial cells and its small lumen contains debris from necrotic tumor cells (Fig. 1A). In uterus, there were several cystic hyperplasia, endometrial inflammations and thickened wall lesions. The most significant lesions were prominent dilated cystic endome-

*Corresponding author

Tel: +82-63-850-6668, Fax: +82-63-850-7308

E-mail: kimoj@wku.ac.kr 
Table 1. Primer sets used in this study

\begin{tabular}{|c|c|c|c|}
\hline Target & Primer & Nucleotide sequence $\left(5^{\prime} \rightarrow 3^{\prime}\right)$ & Product size $(\mathrm{bp})$ \\
\hline \multirow[t]{2}{*}{ FIP } & $\mathrm{F}$ & TAATGCCATACACGAACCAGCT & \multirow{2}{*}{295} \\
\hline & $\mathrm{R}$ & GTGCTAGATTTGTCTTCGGACACC & \\
\hline \multirow[t]{2}{*}{ FeLV } & $\mathrm{F}$ & CTACCCCAAAATTTAGCCAGCTACT & \multirow{2}{*}{468} \\
\hline & $\mathrm{R}$ & AAGACCCCCGAACTAGGTCTTC & \\
\hline \multirow[t]{2}{*}{ FIV } & $\mathrm{F}$ & CCACAATATGTAGCACTTGACC & \multirow{2}{*}{583} \\
\hline & $\mathrm{R}$ & GGGTACTTTCTGGCTTAAGGTG & \\
\hline \multirow[t]{2}{*}{ FPV } & $\mathrm{F}$ & CATTGGGCTTACCACCATTT & \multirow{2}{*}{172} \\
\hline & $\mathrm{R}$ & GGTGCACTATAACCAACCTCAGC & \\
\hline \multirow[t]{2}{*}{ FHV } & $\mathrm{F}$ & CGGGAAAATCCAGTACGAGT & \multirow{2}{*}{383} \\
\hline & $\mathrm{R}$ & AGGAAGAGTTCGGCGGTATT & \\
\hline \multirow[t]{2}{*}{ FCV } & $\mathrm{F}$ & TTCGGCCTTTTGTGTTCC & \multirow{2}{*}{673} \\
\hline & $\mathrm{R}$ & TTGAGAATTGAACACATCAATAGATC & \\
\hline \multirow[t]{2}{*}{ Feline chlamydia } & $\mathrm{F}$ & ATGAAAAAACTCTTGAAATCGG & \multirow{2}{*}{1069} \\
\hline & $\mathrm{R}$ & CAAGATTTTCTAGACTTCATTTTGTT & \\
\hline \multirow[t]{2}{*}{ Babesia spp. } & $\mathrm{F}$ & ATAACCGTGCTAATTGTAGG & \multirow{2}{*}{327} \\
\hline & $\mathrm{R}$ & TGTTATTTCTTGTCACTACC & \\
\hline \multirow[t]{2}{*}{ Ehrlichia spp. } & $\mathrm{F}$ & GGAATTCAGAGTTGGATCATGGCTCAG & \multirow{2}{*}{492} \\
\hline & $\mathrm{R}$ & CGGGATCCCGAGTTTGCCGGGACTTCTTCT & \\
\hline \multirow[t]{2}{*}{ Haemobartonella felis } & $\mathrm{F}$ & AGCAGCAGTAGG GAATCTTCCAC & \multirow{2}{*}{674} \\
\hline & $\mathrm{R}$ & TGCACCACCTGTCACCTCGATAAC & \\
\hline
\end{tabular}

FIP, feline infectious peritonitis; FIV, Feline immunodeficiency virus; FPV, feline panleukopenia virus; FHV, feline herpesvirus; FCV, Feline calicivirus; $\mathrm{F}$, forward; $\mathrm{R}$, reverse.

trial glands, increased proliferations glands and thickness of the surface endometrium resulting in irregular hyperplastic projections into the lumen (Fig. 1B). Hyperplastic cystic glands were different in size and were covered by compacted epithelium that was commonly pressed by glandular secretory components. Calcified lesions were shown focally in the severe hyperplasia endometrium. In the endometrial wall, there were inflammatory cells and mucinous secretory components were covered the endometrial surface. Based on the histopathological examination, this case was diagnosed with feline mammary carcinoma, which is accompanied by endometrial hyperplasia.

The blood samples were tested against feline infectious peritonitis (FIP), FeLV, Feline immunodeficiency virus (FIV), feline panleukopenia virus (FPV), feline herpesvirus (FHV), Feline calicivirus (FCV), feline chlamydia, Babesia spp., Ehrlichia spp., and Haemobartonella felis by polymerase chain reaction (PCR) assay. The primer sequences used for amplification were as Table 1.

Genomic DNAs were extracted from the blood using an AccuPrep Genomic DNA Extraction Kit (Bioneer Corporation, Korea) according to the manufacturer's instructions.

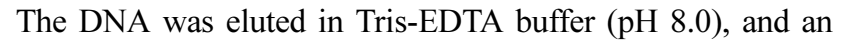
aliquot was used for the PCR amplification. All DNA samples were stored at $-20^{\circ} \mathrm{C}$ until the PCR assays were performed. The template DNA (50 ng) and $20 \mathrm{pmol}$ of each primer were added to a PCR mixture tube (AccuPower PCR
PreMix; Bioneer, Korea) containing 2.5 U of Taq DNA polymerase, $250 \mu \mathrm{M}$ each deoxynucleoside triphosphate, $10 \mathrm{mM}$ Tris- $\mathrm{HCl}(\mathrm{pH} 8.3$ ), $40 \mathrm{mM} \mathrm{KCl}, 1.5 \mathrm{mM} \mathrm{MgCl}$, and the gel loading dye. The volume was adjusted with distilled water to $20 \mu \mathrm{L}$. The reaction mixture was subjected to denaturation at $95^{\circ} \mathrm{C}$ for $2 \mathrm{~min}$ followed by 40 cycles of $95^{\circ} \mathrm{C}$ for $30 \mathrm{sec}$ (denaturation), $54^{\circ} \mathrm{C}$ for $30 \mathrm{sec}$ (annealing), $72^{\circ} \mathrm{C}$ for $30 \mathrm{sec}$ (extension) and a final extension step of $72^{\circ} \mathrm{C}$ for $5 \mathrm{~min}$, and samples were kept at $4^{\circ} \mathrm{C}$ until analysis. Reactions were conducted using My Genie 32 Thermal Block PCR (Bioneer, Korea). Each sample $(8 \mu \mathrm{L})$ was mixed with $2 \mu \mathrm{L}$ loading buffer, and analyzed by electrophoresis in 1.2\% agarose gels stained with $0.5 \mu \mathrm{g} / \mathrm{mL}$ ethidium bromide. The DNA bands were observed under ultraviolet light.

At the end of the PCR assay, all samples were evaluated for the presence of FeLV, FIP, FIV, FPV, FHV, FCV, feline chlamydia, Babesia spp., Ehrlichia spp., and Haemobartonella felis and the result was visualized as a band of 468 base pairs in agarose gel showing FeLV amplicons in samples. However, other feline pathogens were appeared as negative (Fig. 2).

Mammary carcinoma cases have been reported mainly in female cats, and it is suggested that estrogen and progesterone play an important role in mammary carcinoma occurrences. However, the roles of these hormones in the pathogenesis of feline mammary tumors is not cleared [10]. Previous studies support that estrogen and progesterone 


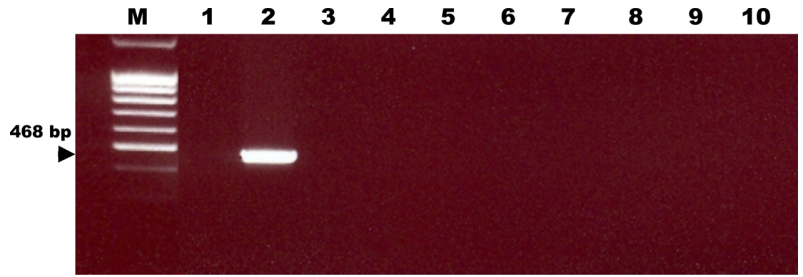

Fig. 2. Amplicons of the sample DNAs (blood) detected by species-specific polymerase chain reactions for the suspected pathogens were identified on a $1.2 \%$ agarose gel electrophoresis. Lane M, size marker; Lane 1, feline infectious peritonitis (-); Lane 2, Feline leukemia virus (+); Lane 3, Feline immunodeficiency virus (-); Lane 4, feline panleukopenia virus (-); Lane 5, feline herpesvirus (-); Lane 6, Feline calicivirus (-); Lane 7, feline chlamydia (-); Lane 8, Babesia spp. (-); Lane 9, Ehrlichia spp. (-); Lane 10, Haemobartonella felis (-).

affect the mammary carcinoma occurrence. Some studies reported that the cats treated with progestin increased the occurrences of mammary tumors. Also, other studies indicate that neuterization may decrease feline mammary tumor occurrences [10]. In another study, cats neuterized at 6 months of age revealed about 7-fold decrease of mammary gland carcinoma incidences compared to the unneuterized cats [4]. Previously studies reported that cats neuterized before 1 year of age were remarkably decreased in mammary tumor occurrences [11]. Another study suggests that mammary tumor in the male cat looks similar to mammary tumor in female cats, with an active negative prognosis in most cats [14]. However, these studies did not include the age-related comparison and nobody has stressed the importance of the ages of neuterization operation on the risk of mammary tumor occurrences. Several studies show that some hormones like as estrogen, progesterone, prolactin, and somatostatin affect mammary tumor cells [13]. Continuous hormone exposure facilitates multiplication of mammary tumor cells and facilitates the occurrences of genetic errors that result in tumor development [13]. It is suggested that a mammary tumor is initiated as multiplication of mammary epithelial cells and proceeds to a precancerous condition, which proliferates and finally infiltrates to the basement membrane and changes into an malignant carcinoma under the effect of hormones [12].

Remarkable changes in the endometrial structure are related to the degeneration of endometrial epithelium, the cystic endometritis, and the cystic hyperplasia of glands and the pyometra [9]. The basic mechanisms associated with these changes are not properly understood. Long-term exposure to megestrol acetate is associated with endometriosis in utero and suppurative endometritis, and progesterone pills can have a similar effect on zoos [8]. Due to available clinical and epidemiological data, it has been long suspected that tumors of the female genital tract of the dog are developed under the influence of ovarian hormones [9]. In this study, the cat had not been fed with a derivative of progesterone like as mege- strol acetate which used commonly both in contraception and hormone replacement therapy.

FeLV is a degenerative retrovirus that causes many diseases such as blood clots, bone marrow anemia, bone marrow disease, and immunosuppression [3]. The FeLVs that cause T-cell tumors in cats are transmitted horizontally [7], especially saliva [6]. Even when viruses infect human cells, T cells are commonly observed [2]. Although many street cats become continuously infected with FeLV, small population of the cats occurred leukemia or lymphoma. The majority of the infected cats induce fatal infections like as the peritonitis. FeLV induces the immune related disease like as lymphoma, immune depression, antiglobulin, and hyper- $\gamma$-globulin, which decreased the immune status related to T cells. [5].

In this study, the cat had feline mammary tumor and uterine endometrial cystic hyperplasia with FeLV infection. It was suggested that this case was related to immune decrease by FeLV infection, although it may be affected by other factors such as ages related to this tumor occurrences. As far as we know, this is the first report of the simultaneous feline mammary carcinoma and uterine endometrial cystic hyperplasia with FeLV infection in a cat.

\section{Acknowledgments}

This research was supported by Wonkwang University, Republic of Korea in 2017.

\section{References}

1. Arjona A, Barquero N, Doménech A, Tejerizo G, Collado VM, Toural C, Martín D, Gomez-Lucia E. Evaluation of a novel nested PCR for the routine diagnosis of feline leukemia virus (FeLV) and feline immunodeficiency virus (FIV). J Feline Med Surg 2007, 9, 14-22.

2. Azocar J, Essex M. Susceptibility of human cell lines to feline leukemia virus and sarcoma virus. J Natl Cancer Inst 1979, 63, 1179-1184.

3. Cotter SM. Feline leukemia virus: pathophysiology, prevention, and treatment. Cancer Invest 1992, 10, 173-181.

4. Dorn CR, Taylor DON, Frye FL, Hibbard HH. Survey of animal neoplasms in Alameda and Contra Costa Counties, California. I. Methodology and description of cases. J Natl Cancer Inst 1968, 40, 295-305.

5. Essex M, McLane MF, Kanki P, Allan J, Kitchen L, Lee TH. Retroviruses associated with leukemia and ablative syndromes in animals and in human beings. Cancer Res 1985, 45 (9 Suppl), 4534s-4538s.

6. Francis DP, Essex M, Hardy WD Jr. Excretion of feline leukemia virus by naturally infected pet cats. Nature 1977, 269, 252-254.

7. Hardy WD, Old LJ, Hess PW, Essex M, Cotter S. Horizontal transmission of feline leukemia virus. Nature 1973, 244, 266-269.

8. Kim KS, Kim O. Cystic endometrial hyperplasia and endometritis in a dog following prolonged treatment of medroxyprogesterone acetate. J Vet Sci 2005, 6, 81-82.

9. Klein MK. Tumors of the female reproductive system. In: 
Withrow SJ, MacEwen EG (eds.). Small Animal Clinical Oncology. 3rd ed. pp. 445-454, WB Saunders, Philadelphia, 2001.

10. Misdorp W, Romijn A, Hart AAM. Feline mammary tumors: a case-control study of hormonal factors. Anticancer Res 1991, 11, 1793-1797.

11. Overley B, Shofer FS, Goldschmidt MH, Sherer D, Sorenmo KU. Association between ovarihysterectomy and feline mammary carcinoma. J Vet Intern Med 2005, 19, 560-563.

12. Russo J1, Lareef MH, Balogh G, Guo S, Russo IH. Estrogen and its metabolites are carcinogenic agents in human breast epithelial cells. J Steroid Biochem Mol Biol
2003, 87, 1-25.

13. Rutteman GR, Misdorp W. Hormonal background of canine and feline mammary tumors. J Reprod Fertil Suppl 1993, 47, 483-487.

14. Skorupski KA, Overley B, Shofer FS, Goldschmidt MH, Miller CA, Sørenmo KU. Clinical characteristics of mammary carcinoma in male cats. J Vet Intern Med 2005, 19, 52-55.

15. Withrow SJ, MacEwen EG. Tumors of the mammary gland. In: Withrow SJ, MacEwen EG (eds.). Small Animal Clinical Oncology. 3rd ed. pp. 455-477, WB Saunders, Philadelphia, 2001. 